\title{
K charakteristickým rysům literárněkritických prací $P$. V. Anněnkova
}

\author{
Josef Šaur (Brno)
}

\begin{abstract}
Abstrakt
Článek definuje charakteristické rysy Anněnkovovy literární kritiky. Pavel V. Anněnkov (1813-1887) patřil v padesátých letech 19. století k výrazným odpůrcům literárněkritických koncepcí radikálních demokratů. Anněnkov bývá považován za významného obhájce estetické stránky literárního dilla, která podle něj nesmí být zastíněna diskusemi o politických či společenských otázkách. Avšak jeho hodnocení literárních děl nelze redukovat pouze na estetické hledisko. Autor dokládá, že Anněnkov ve svých literárních kritikách kladl dưraz také na harmonii a mravní hledisko, a upravuje tak prevládající zjednodušující vnímání Anněnkovova jako literárního kritika. Článek uvádí Anněnkovovy estetické a umělecké postoje do souvislostí dobového ruského liberálního myšlení a ukazuje, že vlivy evropského liberalismu je v ruském prostředí nutno hledat i mimo politickou sféru.
\end{abstract}

\section{Klíčová slova}

literární kritika; literatura; Rusko; 19. století; P. V. Anněnkov; liberalismus; společenské myšlení

\section{Abstract \\ On the Characteristic Features of Literary-Critical Works by Pavel V. Annenkov}

This study describes the characteristic features of Annenkov's literary criticism. Pavel V. Annenkov (1813-1887) was one of the key opponents of the concepts of literary criticism proposed by the radical democrats. He used to be regarded as a strong advocate of the aesthetic qualities of literature, which, in his opinion, could not be superseded by discussions about political or social issues. However, his assessment of literary works can not only be reduced to an aesthetic point of view. The author reports that in his literary criticisms Annenkov also puts emphasis on harmony and on moral viewpoint and thus he adjusts prevailing simplified perception of Annenkov as a literary critic. The study draws parallels between Annenkov's aesthetic and artistic views and the then-current Russian liberal thinking and shows that the influence of European liberalism on the Russian society can also be found outside the sphere of politics.

\section{Key words}

literary criticism; literature; Russia; 19th century; P. V. Annenkov; liberalism; social thought

Text byl zpracován v rámci grantového projektu GA MU „Rusko v kategoriích př̌tel - neprǐtel. Česká reflexe“ (kód MUNI/M/0921/2015). 
V předkládaném článku se zaměříme na vytyčení hlavních charakteristických znaků literárně kritické činnosti $\mathrm{P}$. V. Anněnkova, a to zejména na základě jeho pracích z padesátých let 19. století, které patří v tomto ohledu $\mathrm{k}$ jeho nejplodnějšímu období. Anněnkovovu literárněkritickému dílu (a nikoliv jeho literárním memoárům či cestopisným črtám) se věnujeme především ze dvou důvodů. Jednak tato část jeho díla je stále poměrně málo známá a probádaná, jednak je na ní dobře patrný přesah ruské literární činnosti směrem ke společenskému a v jisté míre i politickému myšlení, tj. v Anněnkovově případě $\mathrm{k}$ liberalismu.

Pavel Vasiljevič Anněnkov (1812-1887) ${ }^{1}$ patří dnes spíše k méně známým postavám ruského literárního života, byt se ve své době, a zejména pak v období od poloviny čtyřicátých až do počátku šedesátých let 19. století, pohyboval v centru ruského literárního dění. Ve čtyřicátých letech 19. století proslul mezi ruskými čtenáři cestopisnými črtami, které zasílal ze svých cest po Evropě - Письма из-за гранииы (1841-1843, Dopisy ze zahraničí) а Парижские писъма (1847-1848, Pařǐ̌ské dopisy). V padesátých letech se Anněnkov věnoval jednak literární kritice, jednak literární historii. Sestavil kritické edice Puškinova díla, jíž doprovodil spisovatelovou biografií, která zaplnila celý první díl sedmisvazkové edice. Dále vydal korespondenci N. V. Stankeviče, kterou tak doplnil o životopisnou studii. Práce o Puškinovi, která představuje počátek vědeckého bádání o tomto velikánovi ruské literatury, Anněnkovovi přinesla uznání současníků. ${ }^{2}$

Od počátku šedesátých let se Anněnkov postupně stahoval z ruského společenského života a pobýval převážně v zahraničí. $\mathrm{V}$ tomtéž desetiletí (v šedesátých letech) napsal Anněnkov ještě několik literárněkritických prací, celkově však svoji publikační činnost utlumil a věnoval se především rodině. $V$ průběhu sedmdesátých let připravoval Anněnkov své vůbec nejznámější dílo Замечательное десятилетие (Мiтог̌ádné desetiletí, 1880), které představuje literární vzpomínky na léta 1838-1848. Anněnkovova memoaristická činnost zastínila zbytek jeho tvorby. To je zřejmé již z počtu pozdějš́ích vydání. Anněnkovovy literárněkritické statě vyšly (společně s dalšími jeho díly) souborně za autorova života v letech $1877-1881^{3}$ a následně až v roce $2000 .{ }^{4}$ Cestopisné črty se dočkaly pouze jedné kritické edice, a to v roce 1983. ${ }^{5}$ Jednu moderní edici zaznamenala i Anněnkovova biografie Puškina. ${ }^{6}$ Naopak jeho literární vzpomínky a nejednalo se jen o již zmíněné Замечательное десятилетие, ale i o další vzpomínkové texty, se těšily a těší velké oblibě

1 Starší sekundární literatura, zejména edice z 19. století, uvádí jak rok narození 1813.

2 OFFORD, Derek: Portraits of early Russian liberals : a study of the thought of T. N. Granovsky, V. P. Botkin, P. V. An nenkov, A. V. Druzhinin, and K. D. Kavelin. Cambridge [etc.]: Cambridge University Press, 1985, s. 136-137.

3 ANNENKOV, Pavel V.: Vospominanija i kriticheskije ocherki. Otdel I-III. Sankt-Peterburg: Tipografija M. Stasjulevicha, 1877-1881.

4 ANNENKOV, Pavel V.: Kriticheskije ocherki. Sost., podgotovka teksta, vstup. statja i primech. I. N. Suchich. Sankt-Peterburg: Izdatelstvo Russkogo Christianskogo gumanitarnogo instituta, 2000. K tomu je třeba doplnit, že vyšlo několik edic shrnujících literárněkritické statě různých autorů určitého období, např. padesátých let 19. století. V nich je Anněnkov zastoupen jedním či dvěma texty.

5 ANNENKOV, Pavel V.: Parizhskije pisma. Izd. podg. I. N. Konobejevskaja. Moskva: Nauka, 1983.

6 ANNENKOV, Pavel V.: Sochinenija Pushkina: S prilozhenijem materialov dlja jego biografi. Avt. statji K. V. Šilov; Avt. kommentarija A. L. Ospovat, N. G. Ochotin. Moskva: Kniga, 1985. 
editorů, nebot jsou opakovaně vydávány - 1892, 1909, 1928, 1960, 1983, $2015 .{ }^{7} \mathrm{~K}$ tomu je třeba doplnit, že kromě zmíněných ruských vydání vyšel v roce 1981 i anglický překlad, který byl dokonce v roce 2016 vydán znovu jako reprint. ${ }^{8}$

Opakovaná vydání Anněnkovových literárních vzpomínek mají samozřejmě svůj důvod, resp. důvody. Anněnkov byl zdatným kronikářem ruského literárního a společenského života a jeho vzpomínky se díky ucelenosti a také nemalému rozsahu řadí k důležitým pramenům k poznání Ruska čtyřicátých let 19. století. Nezapomínejme, že se jedná o dobu živých diskusí v salonech a kroužcích, jejichž obsah nám zprostředkovávají vzpomínky účastníků a zmínky v korespondenci. Navíc Anněnkov patřil ke společensky založeným lidem a díky své přátelské povaze navazoval snadno a rychle kontakty. V dané době se pohyboval v centru literárního a společenského dění. To bývá zpravidla dokládáno třemi epizodami z jeho života. Na počátku čtyřicátých let 19. století pobýval v Římě u Gogola a zapisoval dle jeho diktátu část románu Mrtvé duše. Na konci čtyřicátých let poslal příteli Bělinskému finance na cestu do lázní, kam ho doprovázel a byl přímým svědkem vzniku známého Dopisu $N$. V. Gogolovi. A v polovině zmíněného desetiletí se osobně setkal s Marxem, s nímž si vyměnil i několik dopisů. Anněnkov se setkával a udržoval kontakty i s lidmi, s nimiž nesdílel jejich společenské a politické názory. Ruská spisovatelka a memoáristka Avdotjja Ja. Panajevová (1820-1893) Anněnkova pro tuto jeho vlastnost poněkud uštěpačně popsala jako „literárního chameleona“. ${ }^{9}$ Anněkovovy vzpomínky, přestože se nemohou zbavit autorovy subjektivnosti, představují z výše uvedených důvodů kroniku ruského společenského života let 1838-1848.

Pozdější badatelé sice hojně citovali Anněnkovovy vzpomínky, avšak autor sám zůstával stranou jejich zájmu. Dodnes o něm nevznikla žádná monografie, která by uceleně zpracovávala jeho biografii a dílo. Ze sekundární literatury je tak možné se opírat o dílčí studie zpracovávající určité tematické části Anněnkovova díla, z nichž nemalou část tvoří úvodní studie k výše citovaným edicím jeho prací. Dosud nejuceleněji o Anněnkovovi pojednali znalec ruského společenského myšlení Derek Offord a odborník na ruskou literární kritiku Boris F. Jegorov. ${ }^{10}$ Zajímavé a dosud téměř nevyužité informace k biografii

7 ANNENKOV, Pavel V.: P. V. Annenkov i jego druzja. Literaturnyja vospominanija i perepiska $1835-1885$ godov. Sankt-Peterburg: Izdanije A. S. Suvorina, 1892; ANNENKOV, Pavel V.: Literaturnyja Vospominanija. Sankt-Peterburg: M. Stasjulevich, 1909; ANNENKOV, Pavel V.: Literaturnyje vospominanija. Leningrad, 1928; ANNENKOV, Pavel V.: Literaturnyje vospominanija. Vstup. statja, podgotovka teksta i primechanija V. P. Dorofejeva. Moskva: Goslitizdat, 1960; ANNENKOV, Pavel V.: Literaturnyje vospominanija. Vstup. statja V. I. Kuleshov; Komment. A. M. Dolotova i dr. Moskva: Chudozh. literatura, 1983; ANNENKOV, Pavel V.: Literaturnyje vospominanija. Moskva: Izdatelstvo TERRA: Knizhnyj Klub Knigovek, 2015.

8 ANNENKOV, Pavel V.: The Extraordinary Decade: Literary Memoirs. Edited by Arthur P. Mendel. [S. 1.]: The University of Michigan Press, 2016.

9 PANAJEVA, Avdodja Ja.: Vospominanija. Vstup. statja K. Čukovskij. Primech. G. V. Krasnov, N. M. Fortunatov. Moskva: Pravda, 1986, s. 221.

10 OFFORD, Derek: Portraits of early Russian liberals: a study of the thought of T. N. Granovsky, V. P. Botkin, P. V. Annenkov, A. V. Druzhinin, and K. D. Kavelin. Cambridge [etc.]: Cambridge University Press, 1985, s. 106-143; JEGOROV, Boris F.: Izbrannoje. Esteticheskije idei v Rossii XIX veka. Moskva: Letnij sad, 2009, s. 232-282. Jegorovova kniha představuje souborné vydání dvou starších autorových knih - Борьбa эстетических идей в России середины ХІХ века а Борьба эстетических идей в России 1860-х годов, do nichž Jegorov spojil jednotlivé studie na téma ruské literární kritiky 40.-60. let 19. století. Základem pro 
Anněnkova přinesla studie Nikolaje Žekulina otištěná v edici Anněnkovových dopisů I. S. Turgěněvovi. ${ }^{11}$

Jako literární kritik patřil Anněnkov společně s Vasilijem P. Botkinem (1811-1869) a Alexandrem V. Družininem (1824-1864) k představitelům tzv. čisté či estetické literární kritiky. ${ }^{12} \mathrm{~S}$ jistým zjednodušením lze říci, že odmítali, aby umění plnilo mimo estetických i politické účely, a byli proti didaktickým tendencím či proti snaze spisovatelů vstupovat svými díly do společenských polemik na dobová témata. V tomto ohledu vystupovali jako protiklad literární kritice mladých radikálů N. G. Černyševského a N. A. Dobroljubova. Ovšem tato teze je uplatnitelná jen částečně. Pro ruské zapadniky a později i pro ruské liberály byla vždy typická heterogenita. Sdíleli sice podobné a blízké názory, avšak v mnoha otázkách se názorově lišili. A totéž platí i o literárních a estetických postojích Anněnkova, Družinina i Botkina. Tedy důraz na estetické hledisko je u nich zřejmý, avšak je jim vlastní v rozdílné míře. $V$ konkrétním případě Anněnkova je dosavadní časté zdůrazňování pouze estetických cílů umění př́lišným zjednodušením.

Nejprve se však pozastavme u vysvětlení jednoho rozporu, týkajícího se Anněnkovových názorů na literaturu. $\mathrm{V}$ padesátých letech 19 . století si Anněnkovova literárního mínění velmi považovali např. Turgeněv, Tolstý a další. Anněnkov četl řadu Turgeněvových děl v rukopise a ten je následně podle jeho rad upravoval. Jeho literární kritiky však vyvolávaly jen krátkodobý ohlas. Čím to je? Kvalitu jeho literárněkritických statí snižuje nedůslednost samotného autora. Ǩadu zajímavých názorů, které zachytili jeho přátelé ve svých pamětech či v korespondenci, Anněnkov nikdy nevložil do svých článků. Navíc dle dobových svědectví měl Anněnkov zjevně dar lépe argumentovat v salonních diskusích než v tištěné formě. Již jeho současníci mu vytýkali složitý styl a nejasné vyjadřování myšlenek. ${ }^{13} \mathrm{Na}$ nejednoznačnost Anněnkovovy argumentace upozorňovali opakovaně i pozdější badatelé. ${ }^{14}$ Tento nechtěný rys jeho literárněkritické práce znesnadňuje interpretaci jeho postojů.

Estetické hledisko hrálo v Anněkovových literárněkritických pracích důležitou roli, avšak autor k němu dospívá postupně, částečně pod tlakem společenských změn, které

kapitolu o Anněnkovovi se stala studie JEGOROV, Boris F.: P. V. Annenkov - literator $i$ kritik. Uchenyje zapiski Tartuskogo universiteta 1968, vyp. 209, s. 51-108.

11 ZHEKULIN, Nikolaj G.: Dobrosovestnyj ochevidec. Materialy dlja biografii P. V. Annenkova. In: ANNENKOV, Pavel V.: Pisma k I. S. Turgenevu. Izdanije podgotovili N. N. Mostovskaja, N. G. Žekulin. Kniga 1. Sankt-Peterburg: Nauka, 2005, s. 260-283.

12 Z novějších zpracování zahrnující srovnání děl všech tř́i literárních kritiků srov. SHNEJDER, Konstantin I.: Rannij russkij liberalizm v esteticheskom izmerenii. Voprosy filosofii, 2015, č. 7, s. 41-48; PROZOROV, Valerij V. (red.): Istorija russkoj literaturnoj kritiki. 2-e izd., ispr. i dop. Moskva: Izdatelskij centr «Akademija», 2009, s. 143-149; Ze starších článků srov. JEGOROV Boris F.: «Esteticheskaja kritika» bez laka i degtja (V. P. Botkin, P. V. Annenkov, A. V. Druzhinin). Voprosy literatury, 1965, č. 5, s. 142-160. Problematice estetiky v ruské literární kritice je věnována i monografie MOSER, Charles A.: Esthetics as Nightmare. Russian Literary Theory, 1855-1870. Princeton: Princeton University Press, 1989.

13 SUCHICH, Igor N.: Zhizn i kritika P. V. Annenkova. In: ANNENKOV, Pavel V.: Kriticheskije ocherki. Sost., podgotovka teksta, vstup. statja i primech. I. N. Suchich. Sankt-Peterburg: Izdatelstvo Russkogo Christianskogo gumanitarnogo instituta, 2000, s. 8.

14 Srov. napr. OFFORD, Derek: Portraits of early Russian liberals: a study of the thought of T. N. Granovsky, V. P. Botkin, P. V. Annenkov, A. V. Druzhinin, and K. D. Kavelin. Cambridge [etc.]: Cambridge University Press, 1985, s. 132; JEGOROV, Boris F.: Izbrannoje. Esteticheskije idei v Rossii XIX veka. Moskva: Letnij sad, 2009, s. 248-250. 
Rusko od konce čtyřicátých do konce padesátých let 19. století zažívalo, a co více postupně ho také opouští, resp. upozaduje. Budeme se proto soustředit na výklad jeho postojů v chronologickém sledu. Po smrti Bělinského byl Anněnkov požádán redakcí časopisu Современник о zpracování přehledové studie o ruské literatuře za rok 1848, a tak vznikl článek Заметки о русской литература 1848 года (Poznámky $k$ ruské literatuře za rok 1848, 1849). ${ }^{15} \mathrm{~V}$ jeho závěru autor uznával, že literatura může sehrávat roli ve vzdělávání společnosti. Avšak většinu článku zaujímalo vysvětlení, proč se tak neděje, resp. nemůže dít. Doboví autoři podle Anněnkova totiž př́liš lpěli na zachycování mravních a uměleckých vzorů literární postav, které se stávaly vyprázdněnými př́ílady odtrženými od reality. Anněnkov dokonce soudil, že literární talent a imaginace se mění v řemeslnou činnost. Posteskl si, že literární charaktery jsou dány dopředu a spisovatel tvoří povídku, jako se dělá kočár z jednotlivých součástek, $\mathrm{u}$ čehož není třeba žádného talentu. ${ }^{16}$ Proto kladl důraz na harmonii, tj. uvedení jednotlivých elementů, z nichž je literární postava vystavěna do vzájemného souladu, případně měl být tento soulad dosažen ve vyvrcholení (závěru) děje. Boris Jegorov trefně konstatuje, že požadavek harmonie je v tomto př́i padě odrazem smýšlení umírněných zapadniků (můžeme říci liberálů), kteří důrazem na společenský soulad reagovali na sociální a revoluční otřesy dobové Evropy. ${ }^{17}$

Myšlenku harmonie dále Anněnkov rozvíjel ve stati Романы и рассказы из простонародного быта в 1853 году (Romány a povídky z prostonárodního prostředí za rok 1853, otištěno v časopise Современник 1854). ${ }^{18}$ Anněnkov se v ní vymezil proti tomu, aby literární dílo primárně zachycovalo společenské rozpory a černobílý protiklad dobra a zla, jelikož to vede $\mathrm{k}$ idealizaci literárních postav. To ho vedlo $\mathrm{k}$ závěru, že svět jako takový a svět literatury jsou dvě oddělené entity. Anněnkov tím však nepožadoval (jak by se na první pohled mohlo zdát) odtržení literatury od každodenního života. $\mathrm{V}$ návaznosti na dědictví intelektuálních debat čtyřicátých let 19. století, které zpravidla neměly vyústění ve zcela konkrétní řešení palčivých dobových otázek, se snažil literaturu směřovat $\mathrm{k}$ zachycování bazálních hodnot, nikoliv $\mathrm{k}$ řešení konkrétních problémů. Význam literatury tak podle něj spočíval ve vytyčování a zodpovídání zcela obecných mravních otázek.

U Anněnkova se př́iklon $\mathrm{k}$ obecnému na úkor konkrétního nejvíce projevil ve dvou článcích z poloviny padesátých let 19. století - Характеристики: И. С. Тургенев иЛ. Н. Толcтой (Charakteristiky: I. S. Turgeněv a L. N. Tolstoj, 1855) а Старая и новая критика (Stará a nová kritika, 1856). ${ }^{19}$ Jejich původní časopisecké názvy, které Anněnkov pro pozdější vydání pozměnil, však lépe vyjadřovali důvod, proč je Anněnkov psal - О мысли

15 ANNENKOV, Pavel V.: Vospominanija i kriticheskije ocherki. Otdel II. Sankt-Peterburg: Tipografija M. Stasjulevicha, 1879, s. 23-45. Původní časopisecký název zněl Заметки о русской литературе прошлого года. Мimochodem jedná se o první studii, v níž se v ruském prostředí objevuje označení „realismus“, kterým Anněnkov z cenzurních důvodů nahrazoval pojem „naturální škola“. Zároveň se ho Anněnkov snažil odlišit od naturalismu, který v ruské literatuře označoval jako „pseudorealismus“.

Tamtéž, s. 32.

JEGOROV, Boris F.: Izbrannoje. Esteticheskije idei v Rossii XIX veka. Moskva: Letnij sad, 2009, s. 243-244.

18 ANNENKOV, Pavel V.: Vospominanija i kriticheskije ocherki. Otdel II. Sankt-Peterburg: Tipografija M. Stasjulevicha, 1879, s. 46-83. Původní časopisecký název zněl По поводу романов и рассказов из простонародного быта.

19 ANNENKOV, Pavel V.: Vospominanija i kriticheskije ocherki. Otdel II. Sankt-Peterburg: Tipografija M. 
в произведениях изящной словесности (O ideách v dilech krásného písemnictví) а О значении художественных произведений для общества ( $O$ výzпати uтёleckých děl pro společnost). Anněnkov zde sice upřednostňoval estetické hledisko, ale neodtrhoval umění od reálného života. Umění bylo podle něj výrazem doby, jejím svědectvím a historickým dokumentem..$^{20}$ Zároveň ale zdůrazňoval, že umění není věda. Soudil, že věda zkoumá společnost, zatímco umění společnost odráží, vnímá. Tedy umění realitu uchopuje a zobrazuje jinak než pouhým popisem. Proto Anněnkov stanovil jako základní cíl literárního díla zachycení umělecké (estetické) ideje. ${ }^{21}$ Tohoto cíle měl podle něj spisovatel dosahovat skrze charakter literární postavy (případně postav). Výpovědní síla a životnost umělecké narace podle kritika spočívá v tom, jak literát dokáže vytvořit psychologický profil svých hrdinů, jak v nich zobrazuje jejich mravní postoje a jak tyto postoje vystavuje zkoušce při jednání s dalšími postavami v díle. ${ }^{22}$ A dále Anněnkov tvrdil, že pokud autor za účelem didaktického působení na čtenáře podřizuje jednání literární postavy předem daným ideám, zpronevěřuje se tím uměleckému cíli a dílo ztrácí na svých kvalitách.

Anněnkov se na jedné straně soustředil výhradně na uměleckou stránku díla a vyhýbal se diskusi o společenských a politických otázkách, které byly v dílech explicitně či implicitně autory řešeny. Požadavek na určitou interpretaci reality upozad’oval ve prospěch čistě uměleckých cílů. Na druhou stranu byl přesvědčen, že umění nejlépe odpoví na požadavky společnosti, když bude zcela nezávislé a bez jakýchkoliv omezení. Anněnkov tak zaujímal totožnou pozici jako V. P. Botkin ve studii Básně A. A. Feta (Стихотворения A. A. Фema, 1857). ${ }^{23}$ Botkin v ní o své době psal, že klade na člověka a společnost mravní nároky. A právě morální ideje podle něj posouvají lidskou společnost kupředu a k jejich vyjádření nejlépe slouží umění. Tyto ideje ovlivňují vnitřní duchovní svět člověka, jeho názor na život a jeho každodenní konání. Botkin proto dokonce dovozoval, že tato role činí z umění hluboce praktickou záležitost. ${ }^{24}$

Postoj Anněnkova i Botkina (a můžeme říci, i Družinina) vykazuje v ohledu významu umění pro společnost značný idealismus a s ohledem na bouřlivou dobu počátku vlády Alexandra II. také naivitu. To ovšem souvisí s tím, že ruští raní liberálové se názorově formovali v kroužcích třicátých a čtyřicátých let 19. století a jejich světonázor se opíral o filozofický idealismus. Navíc určitá naivita v reakci na dobové společenské problémy, zejména v přístupu k reformnímu potenciálu samoděržaví, byla charakteristickou vlastností ruského raného liberalismu. Anněnkovův (a netýká se to jen jeho) důraz na umělecké hledisko odpovídal i základní otázce, jíž se ranní ruští liberálové zaobírali

Stasjulevicha, 1879, s. 84-108 a 1-22. Anněnkov v uvedeném vydání při řazení studií nedodržel důsledně jejich chronologickou posloupnost.

Tamtéž, s. 9.

Tamtéž, s. 12.

Tamtéž, s. 99-100.

BOTKIN, Vasilij P.: Literaturnaja kritika. Publicistika. Pisma. Sost., vstup. statja i primech. B. F. Jegorov. Moskva: Sovetskaja Rossija, 1984, s. 192-234.

Tamtéž, s. 195. 
- individuum jako neopakovatelná entita. ${ }^{25}$ Odtud vychází myšlenka svobody jednotlivce $\mathrm{v}$ různorodých konotacích. Jeden ze základních principů liberalismu - individualismus se tak v literární kritice přetavil do úvah o vnitřní harmonii člověka, mravnosti a skutečné kráse a o jejím přísně individuálním vnímání a o hodnotě umění jako nenahraditelného nástroje uchování duchovního světa.

$\mathrm{V}$ předchozím textu jsme se stručně dotkli i Botkinovy studie z roku 1857 o A. A. Fetovi, v níž autor hledisko estetické spojuje s hlediskem mravním. U Anněnkova se etická stránka při posouzení literárního díla, objevuje již v roce 1856 v recenzi na Rodinnou kroniku S. T. Aksakova. ${ }^{26}$ Ovšem naplno Anněnkov etickou stránku upřednostňil před estetickou v recenzi Литературный тип слабаго человека (Literárni typ slabého člověka, otištěno v časopise Атеней 1858). ${ }^{27} \mathrm{~V}$ ní reagoval jednak na Turgeněvovu novelu Asja, jednak na Černyševského známou literární kritiku této novely Ruský člověk na randez-vouz. ${ }^{28}$ Černyševskij prezentoval slabost Turgeněvova hrdiny jako formu morálního ztroskotání, k němuž statkářská šlechta nevyhnutelně směřovala. Vytýkal mu neschopnost konat, nedostatek energie slabost, nerozhodnost a polovičatost. Pozdější historiografie označila ty, na něž Černyševskij mírill, za liberály, což nebylo přesné z hlediska vymezení jejich politických názorů, ale odpovídalo to dobovému diskursu, v němž bylo s pojmem liberál zacházeno značně volně. ${ }^{29}$

Anněnkov Turgeněvova hrdinu vůbec neposuzoval z hlediska estetického a uplatňoval pouze hledisko mravní. Nepopíral slabosti hlavního hrdiny, ale viděl ho jinak než Černyševskij. Celou Anněnkovovou studií se prolíná srovnávání „slabého člověka“ s jeho antipodem „ryzím charakterem“ („цельный характер“). Anněnkov skutečně používal pro druhého jmenovaného uvozovky, čímž dával najevo, že ryzí je zde míněno ironicky. Oba dva typy jsou podle něj vlastně extrémy a protichůdné póly. „Ryzí charakter“ se na první pohled jeví jako rozhodný, energický a akceschopný. Tyto jeho vlastnosti jsou ve skutečnosti výsledkem nedostatku vzdělání. Takoví lidé jednají zcela podle svého naturelu, protože jinou možnost nemají. Naopak předností, ale také prokletím „slabého člověka“ je jeho vzdělání, humanita a vědomí mravních hodnot. Jestliže „slabý člověk“ volí vždy z několika variant, což mu znemožňuje rychle se rozhodnout, pak „ryzí charakter“ ani volbu nečiní, nebot jedná jediným možným způsobem, který je mu vlastní - př́ímočaře, bezhlavě a bez rozmyslu. „Ryzí charakter“ mírí k cíli přímo přes oseté pole, „slabému člověku“ je jasné, že se jedná o nejkratší cestu, ale raději pole obejde. ${ }^{30}$

25 ŠAUR, Josef: Boris Nikolajevič Čičerin o ruských dějinách (Státni škola jako historiografický a společenský fenomén). Brno: Filozofická fakulta, Masarykova univerzita, 2015, s. 131-134.

26 ANNENKOV, Pavel V.: Vospominanija i kriticheskije ocherki. Otdel II. Sankt-Peterburg: Tipografija M. Stasjulevicha, 1879, s. 109-131.

27 Tamtéž, s. 149-172.

28 O Černyševského i Anněnkovově recenzi v kontextu ruského myšlení 50. let 19. století jsme pojednali ve zvláštní studii, z níž v tomto textu vycházíme. ŠAUR, Josef: Ruský časopis Athenaeum a generačni konflikt ve sporu o výklad Turgeněvovy novely Asja. In: POSPÍŠIL Ivo - ŠAUR, Josef a kol.: Generačni konflikt ve slovanských literaturách a kulturách. Brno: Masarykova univerzita, 2016, s. 43-56.

29 Tamtéž, s. 53.

30 Tamtéž, s. 54. 
Obhajoba „slabého člověka“ souvisela s tím, že Anněnkov ho vnímal jako vtělení ruského intelektuála čtyřicátých let 19. století, jež trpěl jistou sebestředností, avšak navzdory různým nedostatkům byl stále představitelem vřelé lidskosti a upřímného idealismu. A to byly v očích Anněnkova důležité hodnoty, které bylo třeba v době radikálního ikonoklasmu chránit. Proti aktivnímu zlu, tak Anněnkov stavěl pasivní udatnost a mravnost. ${ }^{31}$ Při recenzování Turgeněvovy novely přistoupil Anněnkov na rétoriku Černyševského a využil literární recenzi k vyjádření společenských postojů, což už později v takové míře nečinil. Zajímavou okolností je fakt, že v dopise Turgeněvovi Anněnkov Asju z hlediska estetického posuzoval, avšak samotnou recenzi pojal jinak. ${ }^{32}$

Anněnkovovu odpověd' na Černyševského hodnocení Turgeněvovy novely Asja je třeba chápat v jeho díle spíše jako výjimku a odchylku než jako počátek nové tendence, byt’ to korespondovalo $\mathrm{s}$ jeho odmítavými postoji $\mathrm{k}$ názorům radikálních demokratů. ${ }^{33}$ Anněnkovova literární kritika totiž postrádala (s výjimkou recenze Asji) polemičnost a vyznačovala se, budeme-li parafrázovat hodnocení Panajevové, chameleonskou splývavostí s prostředím. Na přelomu padesátých a šedesátých let 19. století se Anněnkovy literárněkritické postoje ustálily a hlavním kritériem přístupu k literárnímu dílu se stal aspekt psychologický a mravní, doplňovaný o hodnocení estetické, v němž se Anněnkov soustředil na zhodnocení poetiky konkrétního autora. ${ }^{34}$ Anněnkov sice pokračoval dále v psaní literárních kritik až do konce šedesátých let 19. století, avšak na počátku sedmdesátých let se stáhl z veřejného života a odstěhoval se do zahraničí a Rusko navštěvoval jen sporadicky. Výrazně též klesl jeho zájem o ruskou literaturu a vủbec o dění v Rusku.

Anněnkovy literárně kritické postoje od konce čtyřicátých let do konce padesátých let 19. století prošly nezanedbatelným vývojem a nelze je redukovat pouze na prosazování estetického hlediska. Anněnkov sice uznával, že umění je světem samo o sobě a je tedy odděleno od reálného světa, to ovšem neznamenalo jejich vzájemné odtržení. Naopak umělecké ztvárňování mravních idejí mělo podle něj pro společnost zásadní význam. Anněnkov uznával, že umění a literatura mohou působit na společnost a dokonce ji tak

31 OFFORD, Derek: Portraits of early Russian liberals: a study of the thought of T. N. Granowsky, V. P. Botkin, P. V. Annenkov, A. V. Druzhinin, and K. D. Kavelin. Cambridge [etc.]: Cambridge University Press, 1985, s. 134-136; JEGOROV, Boris F.: Izbrannoje. Esteticheskije idei v Rossii XIX veka. Moskva: Letnij sad, 2009, s. 261-262.

32 SUCHICH, Igor N.: Zhizn i kritika P. V. Annenkova. In: ANNENKOV, Pavel V.: Kriticheskije ocherki. Sost., podgotovka teksta, vstup. statja i primech. I. N. Suchich. Sankt-Peterburg: Izdatelstvo Russkogo Christianskogo gumanitarnogo instituta, 2000, s. 17-18.

33 V roce 1857 vydal Anněnkov životopis V. N. Stankeviče, kterého představil jako určitý předobraz ruských intelektuálů čtyřicátých let 19. století a jejich donkichotských snah a cílů. Anněnkov nepsal jen biografii jedince, ale zachycoval myšlenky jedné generace, kterou stavěl do protikladu k radiálním demokratům. Podobně se Anněnkov vrátil ke svým poznámkám na dobu strávenou s Gogolem a v roce 1857 vydal memoárovou stał Николай Василвевич Гоголь в Риме, летом 1841 года (Nikolaj Vasilejvič Gogol v Ř́mě v létě roku 1841). V ní líčil životní styl Italů, který nepodléhá času a dobovým názorovým třenicím, jako by je zajímalo jen to věčné. Mezi řádky zde čteme srovnání s ruskou realitou plnou napětí. Jako varování před radikalismem, poryvy doby a revolučním nebezpečím vydal Anněnkov v letech 1859 a 1862 postupně ve třech částech vzpomínky na revoluci roku 1848, jíž byl svědkem v Paříži.

34 SUCHICH, Igor N.: Zhizn i kritika P. V. Annenkova. In: ANNENKOV, Pavel V.: Kriticheskije ocherki. Sost., podgotovka teksta, vstup. statja i primech. I. N. Suchich. Sankt-Peterburg: Izdatelstvo Russkogo Christianskogo gumanitarnogo instituta, 2000, s. 20. 
vzdělávat, ale aby tento vliv přinesl pozitivní výsledky, nesmí se jednat o autorský záměr. Umělecká tvorba měla být v jeho pojetí čirou imanentní imaginací. To postupně prosazoval důrazem na harmonii všech elementů charakteru literárního hrdiny a následně vytyčením jediného - estetického - cíle umění. V reakci na vnímání role umění radikálními demokraty apeloval Anněnkov na stránku mravní, jejímž zdůrazňováním čelil nebezpečí společenských otřesů.

\section{Literatura}

ANNENKOV, Pavel V.: Kriticheskije ocherki. Sost., podgotovka teksta, vstup. statja i primech. I. N. Suchich. Sankt-Peterburg: Izdatelstvo Russkogo Christianskogo gumanitarnogo instituta, 2000.

ANNENKOV, Pavel V.: Literaturnyja Vospominanija. Sankt-Peterburg: M. Stasjulevich, 1909.

ANNENKOV, Pavel V.: Literaturnyje vospominanija. Leningrad, 1928.

ANNENKOV, Pavel V.: Literaturnyje vospominanija. Moskva: Izdatelstvo TERRA: Knizhnyj Klub Knigovek, 2015.

ANNENKOV, Pavel V.: Literaturnyje vospominanija. Vstup. statja V. I. Kuleshov; Komment. A. M. Dolotova i dr. Moskva: Chudozh. literatura, 1983.

ANNENKOV, Pavel V.: Literaturnyje vospominanija. Vstup. statja, podgotovka teksta i primechanija V. P. Dorofejeva. Moskva: Goslitizdat, 1960.

ANNENKOV, Pavel V.: P. V. Annenkov i jego druzja. Literaturnyja vospominanija i perepiska 1835 1885 godov. Sankt-Peterburg: Izdanije A. S. Suvorina, 1892.

ANNENKOV, Pavel V.: Parizhskije pisma. Izd. podg. I. N. Konobejevskaja. Moskva: Nauka, 1983.

ANNENKOV, Pavel V.: Sochinenija Pushkina: $S$ prilozhenijem materialov dlja jego biografii. Avt. statji K. V. Šilov; Avt. kommentarija A. L. Ospovat, N. G. Ochotin. Moskva: Kniga, 1985.

ANNENKOV, Pavel V.: The Extraordinary Decade: Literary Memoirs. Edited by Arthur P. Mendel. [S. 1.]: The University of Michigan Press, 2016.

ANNENKOV, Pavel V.: Vospominanija i kriticheskije ocherki. Otdel I-III. Sankt-Peterburg: Tipografija M. Stasjulevicha, 1877-1881.

BOTKIN, Vasilij P.: Literaturnaja kritika. Publicistika. Pisma. Sost., vstup. statja i primech. B. F. Jegorov. Moskva: Sovetskaja Rossija, 1984.

JEGOROV Boris F.: «Esteticheskaja kritika» bez laka i degtja (V. P. Botkin, P. V. Annenkov, A. V. Druzhinin). Voprosy literatury, 1965, č. 5, s. 142-160.

JEGOROV, Boris F.: Izbrannoje. Esteticheskije idei v Rossii XIX veka. Moskva: Letnij sad, 2009.

JEGOROV, Boris F.: P. V. Annenkov - literator $i$ kritik. Uchenyje zapiski Tartuskogo universiteta 1968, vyp. 209, s. 51-108.

MOSER, Charles A.: Esthetics as Nightmare. Russian Literary Theory, 1855-1870. Princeton: Princeton University Press, 1989.

OFFORD, Derek: Portraits of early Russian liberals: a study of the thought of T. N. Granovsky, V. P. Botkin, P. V. Annenkov, A. V. Druzhinin, and K. D. Kavelin. Cambridge [etc.]: Cambridge University Press, 1985.

PANAJEVA, Avdodja Ja.: Vospominanija. Vstup. statja K. Čukovskij. Primech. G. V. Krasnov, N. M. Fortunatov. Moskva: Pravda, 1986. 
PROZOROV, Valerij V. (red.): Istorija russkoj literaturnoj kritiki. 2-e izd., ispr. i dop. Moskva: Izdatelskij centr «Akademija», 2009.

SHNEJDER, Konstantin I.: Rannij russkij liberalizm v esteticheskom izmerenii. Voprosy filosofii, 2015, č. 7, s. 41-48.

ŠAUR, Josef: Boris Nikolajevič Čičerin o ruských dějinách (Státní škola jako historiografický a společenský fenomén). Brno: Filozofická fakulta, Masarykova univerzita, 2015.

ŠAUR, Josef: Ruský časopis Athenaeum a generačni konflikt ve sporu o výklad Turgeněvovy novely Asja. In: POSPÍŠIL Ivo - ŠAUR, Josef a kol.: Generačni konflikt ve slovanských literaturách a kulturách. Brno: Masarykova univerzita, 2016, s. 43-56.

ZHEKULIN, Nikolaj G.: Dobrosovestnyj ochevidec. Materialy dlja biografii P. V. Annenkova. In: ANNENKOV, Pavel V.: Pisma $k$ I. S. Turgenevu. Izdanije podgotovili N. N. Mostovskaja, N. G. Žekulin. Kniga 1. Sankt-Peterburg: Nauka, 2005, s. 260-283.

\section{Mgr. Josef Šaur, Ph.D.}

Ústav slavistiky

Filozofická fakulta, Masarykova univerzita

Arna Nováka 1, 60200 Brno, Česká republika

saur@phil.muni.cz 